\title{
Research of Structural Changes in the Northwestern Economic Region in the Medium Term
}

\author{
Minin I.L. \\ Yaroslav-the-Wise Novgorod State University, \\ Veliky Novgorod, Russia, \\ Ivan.Minin@novsu.ru
}

\begin{abstract}
The article is intended to research the development of changes in the structure of homogeneous industries with the aim of creating an optimal structure of the national economy using relative competitive advantages and capable of innovative transformations. The technique of bringing two qualitatively heterogeneous classifications of sectors - OKVED-1 (2007) and OKVED-2 (2018) - to a comparable form is described and the author's approach to the sectoral structure has been formed. The trend analysis and comparative method were used to predetermine the main directions of the development of sectors (and the dynamics were identified) of the Northwestern economic region (except for the federal city of St. Petersburg) and also the basic sectors were identified: manufacturing industries, transport and communication, trade and servicing of durable goods, construction - by using the resources of which, it is possible to overcome the industrial-agrarian nature of the dynamics and contribute to the innovative development of the tertiary sector, which will predetermine the stability of the national economy due to the adjustment of the growth dynamics of homogeneous industries in order to overcome the consequences of socio-economic instability and the depressive tone of the development of Leningrad, Novgorod, and the Pskov oblasts. The need for continued structural adjustment for the future development of the region as a highly developed one is established. The active involvement of public authorities in the restructuring of the region will also allow changing the image of the region at the Russian and international levels.
\end{abstract}

Keywords-basic sectors of the economy, the Northwestern economic region, comparability of economic activity types, structural changes in the national economy, trend analysis of sectoral dynamics, sustainable development of the region

\section{INTRODUCTION}

Structural changes in the region's economy are currently the leading factor in optimizing economic development and improving relative competitiveness for certain major sectors of the national economy [1].

The most effective regulation of sectoral development can lead to significant results in transforming the socio-economic sphere of the region, developing innovation studies based on the use of sectoral advantages, which is shown by the experience of developed countries [2].

Also, the implementation of the optimal sectoral structure of the region solves the key contradictions of the problem oblasts due to the development of those sectors that have not only a strategic need, but also, implementing which, the region can fully realize its not only absolute but also relative competitive advantages [3].

The Russian economy has quite recently embarked on the path of structural adjustment, which entails the need and importance of solving the problems of reformatting the national economy, especially in the oblasts of the European part of Russia [4]. In these oblasts, the task is not to create a full range of economic sectors, but to transform them in such a way that they contribute to facilitating the mainstreaming of competitive advantages and improve their investment attractiveness [5].

The Northwestern economic region is one of the key economic centers for the development of the Russian economy, which, in Soviet times had a high rate of sectoral development, but due to the implementation of negative factors of the country's restructuring, it became a depressed region [6]. The study excludes the city of St. Petersburg as a special phenomenon of the development of an urbanized sectoral structure.

\section{PROBLEM STATEMENT}

To consider and investigate the possible development and structure of the sectors of the Northwestern economic region (excluding the federal city of St. Petersburg) for the mediumterm period 2021-2025, which will make it possible to determine the basic sectors of the region and predetermine the main directions of the innovative transformation of the unified national economy of Leningrad, Novgorod, and Pskov oblasts. Based on the determination of growth rates, it is possible to predetermine the state of the significant sectors of the region through which it is possible to provide resources for the activities carried out and on which the general economic situation in the region depends. 
The questions of this research are:

- the dynamics of the development of the sectors and sectoral structure of the Northwestern economic region (except for the federal city of St. Petersburg) for the period 2021-2025;

- determination of the basic sectors of the region and their dynamics for the medium term;

- determination of the general structural state of the region.

The research goal is to determine the needs of the structural transformation of the Northwestern economic region in the medium term, taking into account the dynamics of the development of the sectoral complex in order to optimize the national economy of the territory and the development of relative competitive advantages.

\section{RESEARCH METHODS}

To achieve the goal of the research, the methodology consisting of the use of the method of trend analysis, structural comparison, the use of the coefficient of determination to find the probability of the development of industries, the calculation of the function of the Gross regional product with the determination of the probability of dynamics, and the method of reduction to a qualitatively general classification of the sectoral structure with the transformation from the structures of OKVED-1 and OKVED-2 was used.

To initially bring the analysis data to a comparable form, it is necessary to transform the two sets of sectors in order to obtain a representative sample of the trend. Using the table of the transition of sectors OKVED-1 (2007) and OKVED-2 (2016), we create a certain set of homogeneous industries that form the Gross regional product (Table I).

TABLE I.

CONVERSION OF OKVED-1 (2007) AND OKVED-2 (2016) TO A COMMON SET OF HOMOGENEOUS SECTORS (INDUSTRIES)

\begin{tabular}{|c|c|c|}
\hline OKVED-1 & OKVED-2 & Common sectors \\
\hline Agriculture, hunting, and forestry & \multirow{2}{*}{$\begin{array}{l}\text { Agriculture, forestry, hunting, fishing, and fish } \\
\text { farming }\end{array}$} & \multirow{2}{*}{ Agriculture } \\
\hline Fishing, fish farming & & \\
\hline Mineral extraction & Mineral extraction & Mineral extraction \\
\hline Manufacturing industries & Manufacturing industries & Manufacturing industries \\
\hline \multirow{2}{*}{$\begin{array}{l}\text { Production and distribution of electricity, gas, and } \\
\text { water }\end{array}$} & $\begin{array}{l}\text { Provision of electricity, gas, and steam; air } \\
\text { conditioning }\end{array}$ & \multirow[b]{2}{*}{ Housing maintenance and utilities } \\
\hline & $\begin{array}{l}\text { Water supply; wastewater disposal, waste } \\
\text { collection and disposal, pollution elimination } \\
\text { activities }\end{array}$ & \\
\hline Construction & Construction & Construction \\
\hline $\begin{array}{l}\text { Wholesale and retail trade; repair of vehicles, } \\
\text { motorcycles, household goods, and personal items }\end{array}$ & $\begin{array}{l}\text { Wholesale and retail trade; repair of vehicles and } \\
\text { motorcycles }\end{array}$ & Trade and servicing of durable goods \\
\hline Hotels and restaurants & Hotel and catering activities & Hotels and restaurants \\
\hline \multirow{2}{*}{ Transport and communication } & Transportation and storage & \multirow{2}{*}{ Transport and communication } \\
\hline & Information and communication activities & \\
\hline Financial activities & Financial and insurance activities & Financial activities \\
\hline $\begin{array}{l}\text { Real estate operations, leasing, and the provision of } \\
\text { services }\end{array}$ & $\begin{array}{l}\text { Real estate operations, leasing, and the provision of } \\
\text { services }\end{array}$ & $\begin{array}{l}\text { Real estate operations, leasing, and the provision of } \\
\text { services }\end{array}$ \\
\hline \multirow{2}{*}{$\begin{array}{l}\text { Public administration and military security; social } \\
\text { insurance }\end{array}$} & $\begin{array}{l}\text { Administrative activities and related additional } \\
\text { services }\end{array}$ & \multirow{2}{*}{$\begin{array}{l}\text { Public administration and military security; social } \\
\text { insurance }\end{array}$} \\
\hline & $\begin{array}{l}\text { Public administration and military security; social } \\
\text { insurance }\end{array}$ & \\
\hline \multirow{2}{*}{ Education } & Professional, scientific, and technical activities & \multirow{2}{*}{ Education } \\
\hline & Education & \\
\hline Health care and social services & Activities in the field of health and social services & Health care \\
\hline $\begin{array}{l}\text { Provision of other communal, social, and personal } \\
\text { services }\end{array}$ & $\begin{array}{l}\text { Activities in the field of culture, sports, leisure, and } \\
\text { entertainment }\end{array}$ & \multirow{2}{*}{$\begin{array}{l}\text { Provision of other communal, social, and personal } \\
\text { services }\end{array}$} \\
\hline Household activities & Provision of other types of services & \\
\hline
\end{tabular}

As a result of the transformation, 14 industries of the common type were determined for the analysis.

To determine the general formula for the development of the Gross regional product, it is necessary to sum up the functions of all transformed industries (1):

$$
Y \operatorname{grp}(x)=\sum_{n=1}^{J}(Y j), \text { million rubles }
$$

Where:

$\mathrm{Yj}$ - a function of a transformed industry, according to Table I;

$\mathrm{X}-$ an independent time variable used in the period 20042025 and corresponding to the condition $X \in[1 ; 22]$. 
To identify the level of reliability of a function, the method of summing the coefficients of determination of all sectoral trends with the correcting coefficient of the arithmetic average fraction was used (2):

$$
Y \operatorname{grp}(x)=\sum_{n=1}^{J}\left(D j \text { average } R^{\wedge} 2 J\right), \%
$$

Where:

$\mathrm{Dj}$ - an arithmetic mean of the value of the function of the $\mathrm{j}$-th sector in the Gross regional product for the period 2021 2025, \%;

$R 2 j$ - the coefficient of determination of the trend of the $j$ th sector, shares.

To determine a basic sector, we use indicators with values above the arithmetic average in a sector. $\mathrm{Yj}$ is a basic sector if the value is more than $100 / \mathrm{n}$ ( $\mathrm{n}$ is the number of sectors), that is, the value will be $7.14 \%$

\section{RESUlts}

Having coducted research on the trends (3.1-3.13, million rubles) of sectoral development, it is possible to determine the nature of the sectors' development. Development trends are represented by nonlinear functions in most cases, which indicates the accelerating dynamism of sectoral changes and thereby reflects the ongoing restructuring of the region. By the nature of the industry dynamics, the following groups have been distinguished:

- Sectors with uniform development: housing maintenance and utilities, trade and service of durable goods, hotels and restaurants. They are characterized by completed structural transformations and stable growth, which indicates the stability of the industries to externally unfavorable factors [7].

- Sectors with uneven polynomial development: agriculture, manufacturing industries, transport and communication, financial activities, real estate operations, leasing, and the provision of services, public administration and military security; social insurance, health care, and provision of other communal, social, and personal services. They are characterized by a transitional nature of development to a uniform one with a dynamic change of a sectoral product; with unfavorable macroeconomic factors, a sectoral crisis may occur and, as a result, these sectors require state control to support them in crisis conditions [8].

- Sectors with uneven power-law development: mineral extraction, construction, and education. They are characterized by a stable development transitioning to a linear one, with a slowdown in development rates. They are more crisis-resistant than polynomial ones, but from a strategic perspective, stagnation is possible [9].

There is a positive growth trend in all sectors, except for financial activities, where a crisis has been observed since September, 2018, and also there is a high probability of a crisis in the field of real estate operations, leasing, and the provision of services in May, 2036.

$$
\begin{gathered}
\text { Ya }=189.27 * x^{2}+2342.6 x+21737, R^{2}=0.9481(3.1) \\
\text { Yme }=1409,2 * x^{0.7377}, R^{2}=0.8279(3.2) \\
\text { Ymi }=1139.9 * x^{2}+8463.1 \mathrm{x}+71850, R^{2}=0.9928(3.3) \\
\text { Yhmu }=5034.2 \mathrm{x}+8217, R^{2}=0.9695(3.4) \\
\mathrm{Yc}=19410 * x^{0.772}, R^{2}=0.9262(3.5) \\
\text { Ytsdg }=10303 x+20226, R^{2}=0.9951(3.6) \\
\text { Yhr }=840.81 x+824.77, \quad R^{2}=0.9752(3.7) \\
\text { Ytc }=299.43 * x^{2}+6068.8 \mathrm{x}+37423, R^{2}=0.9960(3.8) \\
\text { Yfa }=-13.836 * x^{2}+435.34 x-642.08, R^{2}=0.8294(3.9) \\
\text { Yreo }=-141.96 * x^{2}+9481.2 x-4794.1, R^{2}=0.9532(3.10) \\
Y \text { pamssi }=130.56 * x^{2}+3276.2 x+7076.3 R^{2}=0.9891(3.10) \\
Y \mathrm{e}=4399.9 * x^{0,8518}, R^{2}=0.8642(3.11) \\
Y \mathrm{hc}=54.149 * x^{2}+2815.8 x+4794.1, R^{2}=0.9952(3.12) \\
Y \text { pocsps }=29.937 * x^{2}+678.71 x+1637.8, R^{2}=0.9837(3.13)
\end{gathered}
$$

Where:

Ya, Yme, Ymi, Yhmu, Yc, Ytsdg, Yhr, Ytc, Yfa, Yreo, Ypamssi, Ye, Yhc, Ypocsps - the development trends of the sectors (agriculture, mineral extraction, manufacturing industries, housing maintenance and utilities, construction, trade and servicing of durable goods, hotels and restaurants, transport and communication, financial activities, real estate operations, leasing, and the provision of services, public administration and military security; social insurance, education, health care, provision of other communal, social, and personal services) of the Northwestern economic region, million rubles;

$\mathrm{X}$ - an independent temporary variable used in the period 2004-2025 and corresponding to the condition $X \in[1 ; 22]$.

By means of calculations, the sectoral structure (Table II) and the general development trend of the region were identified (4):

$$
\begin{gathered}
Y \operatorname{grp}(x)=1556.89 x^{2}+44705.56 x+4399.9 x^{0.8518}+ \\
19410 x^{0.772}+1409.2 x^{0.7377} \\
R^{2}=0.9748, \text { million rubles }(4)
\end{gathered}
$$

The basic sectors are identified: manufacturing industries $(33.12 \%)$, transport and communication $(13.24 \%)$, trade and servicing of durable goods $(10.76 \%)$, construction $(9.33 \%)$ (Fig. 1).

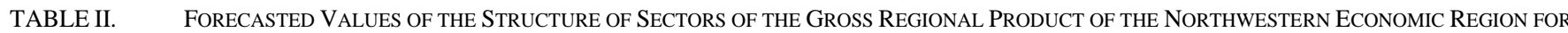
2021-2025, SHARES

\begin{tabular}{|l|c|c|c|c|c|c|c|c|}
\hline \multicolumn{1}{|c|}{ Sector } & $\mathbf{2 0 2 1}$ & $\mathbf{2 0 2 2}$ & $\mathbf{2 0 2 3}$ & $\mathbf{2 0 2 4}$ & $\mathbf{2 0 2 5}$ & $\begin{array}{c}\text { Average } \\
\text { share, \% }\end{array}$ & $\begin{array}{c}\text { Determination } \\
\text { coefficient }\end{array}$ & $\begin{array}{c}\text { Share of } \\
\text { contribution to } \\
\text { probable GRP }\end{array}$ \\
\hline Agriculture & 6.75 & 6.80 & 6.86 & 6.91 & 6.97 & 6.86 & 0.9481 & 6.50 \\
\hline Mineral extraction & 0.64 & 0.63 & 0.61 & 0.60 & 0.58 & 0.61 & 0.8279 & 0.51 \\
\hline Manufacturing industries & 31.99 & 32.56 & 33.13 & 33.68 & 34.22 & 33.12 & 0.9908 & 32.81 \\
\hline
\end{tabular}




\begin{tabular}{|l|c|c|c|c|c|c|c|c|}
\hline Housing maintenance and utilities & 5.33 & 5.25 & 5.18 & 5.10 & 5.03 & 5.18 & 0.9695 & 5.02 \\
\hline Construction & 9.74 & 9.53 & 9.32 & 9.12 & 8.92 & 9.33 & 0.9262 & 8.64 \\
\hline $\begin{array}{l}\text { Trade and servicing of durable } \\
\text { goods }\end{array}$ & 11.09 & 10.92 & 10.75 & 10.59 & 10.43 & 10.76 & 0.9951 & 10.70 \\
\hline Hotels and restaurants & 0.86 & 0.85 & 0.84 & 0.83 & 0.82 & 0.84 & 0.9642 & 0.81 \\
\hline Transport and communication & 13.13 & 13.19 & 13.24 & 13.29 & 13.35 & 13.24 & 0.9960 & 13.19 \\
\hline Financial activities & 0.15 & 0.13 & 0.12 & 0.11 & 0.10 & 0.12 & 0.8294 & 0.10 \\
\hline $\begin{array}{l}\text { Real estate operations, leasing, and } \\
\text { the provision of services }\end{array}$ & 6.46 & 6.27 & 6.09 & 5.90 & 5.71 & 6.09 & 0.9532 & 5.80 \\
\hline $\begin{array}{l}\text { Public administration and military } \\
\text { security; social insurance }\end{array}$ & 5.84 & 5.89 & 5.93 & 5.98 & 6.02 & 5.93 & 0.9891 & 5.87 \\
\hline Education & 2.78 & 2.73 & 2.68 & 2.64 & 2.59 & 2.68 & 0.8642 & 2.32 \\
\hline Health care & 3.98 & 3.97 & 3.97 & 3.96 & 3.96 & 3.97 & 0.9952 & 3.95 \\
\hline $\begin{array}{l}\text { Provision of other communal, } \\
\text { social, and personal services }\end{array}$ & 1.27 & 1.28 & 1.29 & 1.30 & 1.31 & 1.29 & 0.9837 & 1.27 \\
\hline
\end{tabular}

There is a modest increase in the share of the main sectors by $0.98 \%$ (an increase of $1.48 \%$ ), which indicates a trend towards specialization of the region. Manufacturing industries and transport and communications tend to grow by $2.23 \%$ (an increase of $6.98 \%$ ) and $0.22 \%$ (an increase of

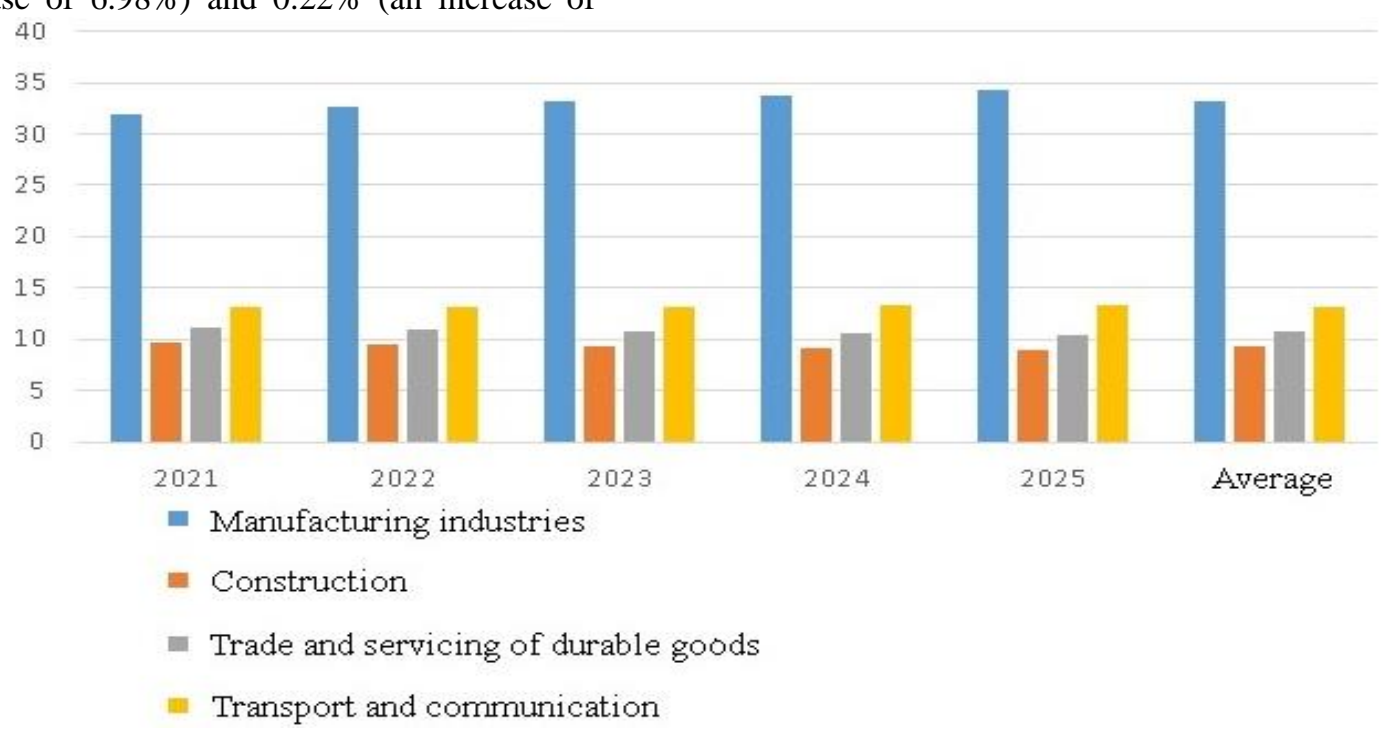

Fig. 1. Dynamics of the structure of the basic sectors of the Northwestern economic region for the period 2021-2025, $\%$

Trends of change in the structure are observed (Table III):

- a decrease in the share of the economy of services (with the exception of the sphere of transport and communication, public services, and other services provided by institutions of culture, sports and households);

- a significant growth of manufacturing industries;

- in the primary sector, there is a contradictory trend an increase in the share of agricultural production, but a significant decrease in the share of mineral extraction.

\section{CONCLUSION}

The development of the Northwestern economic region (with the exception of the federal city of St. Petersburg) is uneven and has specific features of development. Taking into
$1.64 \%$ ), while construction and trade and servicing of durable goods have a risk of a decrease in their share in the structure by $-0.82 \%$ (a decline of $8.45 \%$ ) and $-0.65 \%$ (a decline of $5.87 \%)$. 
communication, trade and servicing of durable goods, construction.

This structure indicates the industrial-agrarian nature of the development of the territory with the use of the functions of a distribution hub between the regions of Russia and Belarus, Finland and Estonia and a sports and tourist center [13].
Service industries are stagnating, creating future volatility in investment activity and in the attractiveness as an innovation center [14].

State support for the development of infrastructure of the development of services is important, including the development of housing maintenance and utilities as the fundamental base of the service industries.

TABLE III. DYNAMICS OF THE STRUCTURE OF THE NORTHWESTERN ECONOMIC REGION FOR 2021-2025

\begin{tabular}{|l|c|c|}
\hline \multirow{2}{*}{\multicolumn{1}{|c|}{ Sector }} & \multicolumn{2}{c|}{ Deviation } \\
\cline { 2 - 3 } & Absolute, shares & Relative, $\%$ \\
\hline Agriculture & 0.22 & 3.24 \\
\hline Mineral extraction & -0.06 & -9.08 \\
\hline Manufacturing industries & 2.23 & -6.98 \\
\hline Housing maintenance and utilities & -0.30 & -5.61 \\
\hline Construction & -0.82 & -8.45 \\
\hline Trade and servicing of durable goods & -0.65 & -5.87 \\
\hline Hotels and restaurants & -0.04 & -5.06 \\
\hline Transport and communication & 0.22 & 1.64 \\
\hline Financial activities & -0.05 & -35.25 \\
\hline Real estate operations, leasing, and the provision of services & -0.75 & -11.64 \\
\hline Public administration and military security; social insurance & 0.18 & 3.02 \\
\hline Education & -0.19 & -6.97 \\
\hline Health care & -0.02 & -0.40 \\
\hline Provision of other communal, social, and personal services & 0.04 & 3.40 \\
\hline
\end{tabular}

If state support measures for the tertiary sector are not applied, there will be an increase in the industrial nature of the development of the territory, an increase in the importance of cooperation with foreign regions in the field of import of services (supply of electricity, receipt of educational and medical services, a decrease in the total volume of other services), an increase in capital outflow, and a deterioration in the image of the region [15].

\section{References}

[1] P. Adamisin, R. Kotulic and I. Kravcakova-Vozarova, "Legal Form Of Agricultural Entities As A Factor In Ensuring The Sustainability Of The Economic Performance Of Agriculture", Agric. Econ., Czech, vol. 63, pp. 80-92.

[2] A. Pawlewicz and K. Pawlewicz, "Regional Differences In Agricultural Production Potential In The European Union Member States. In: Proceedings Of The 2018 International Conference Economic Science For Rural Development", Jelgava, LLU ESAF, May 9-11, 2018, vol. 47, pp. 483-489. DOI: https://doi.org/10.22616/ESRD.2018.056

[3] L. Echazu and M. Heintzelman, "Environmental Regulation And Love For Variety", Review of International Economics, 2018, vol. 27, pp. 413-429.

[4] M. Anokhina, "Parameters of the strategy for managing the economic growth of agricultural production in Russia", Agric. Econ, Czech, 2020, vol. 66, pp. 140-148.
[5] T. Siudek and A. Zawojska, "Competitiveness In The Economic Concepts, Theories, And Empirical Research", Acta Scientiarum Polonorum, Oeconomia, 2014, vol. 13, pp. 91-108.

[6] A.N. Bufetova, A.A. Khrzhanovskaya and E.A. Kolomak, "Cultural Heterogeneity and Economic Development in Russia", Journal of Siberian Federal University, Humanities \& Social Sciences, 2020, vol. 13(4).

[7] H. Alem, "Effects Of Model Specification, Short-Run, And Long-Run Inefficiency: An Empirical Analysis Of Stochastic Frontier Models", Agric. Econ, Czech, 2018, vol. 64, pp. 508-516.

[8] P. Dasgupta and K. Mukhopadhyay, "Pollution Hypothesis And Indian'S Intra-Industry Trade: An Analysis", International Journal of Innovation and Sustainable Development, 2018, vol. 12, pp. 287-307. DOI: https://doi.org/10.1504/IJISD.2018.091538

[9] J. Lee, "Non-Linear Relationships Among Related Party Transactions, Financial Characteristics, Corporate Governance, And Corporate Value - Analysis Of High-Growth And Low-Growth Food Firms", Agric. Econ, Czech, 2019, vol. 65, pp. 123-132.

[10] G. Kolackova, I. Krejci and I. Ticha, "Dynamics Of The Small Farmers' Behaviour - Scenario Simulations", Agric. Econ, Czech, 2017, vol. 63, pp. 103-120.

[11] Huda Miftachul, Mulyadi Dedi, Hananto April Lia, Nor Muhamad Nasrul Hisyam, Mat Teh Kamarul Shukri and Don Abdul Ghafar, "Empowering Corporate Social Responsibility (CSR): Insights From Service Learning”, Social Responsibility Journal, 2018, vol. 14, pp. 875-894. DOI: https://doi.org/10.1108/SRJ-04-2017-0078

[12] M.M. Omarov, "Innovative Development Of The Russian Economy And Recommendations For Improving The Infrastructure And Management System For Innovation Activities", Scientific works of the Free Economic Society of Russia, 2017, vol. 203(1), pp. 307-320.

[13] D.L. Minin, "Investments Features In Order To Ensure Sustainable Development In The Longterm", The European Proceedings of Social 
\& Behavioural Sciences EpSBS, CIEDR 2018, Future Academy, 2020, pp. 579-589.

[14] Y.N. Wang, L. Jin and H. Mao, "Farmer Cooperatives' Intention To Adopt Agricultural Information Mediating Effects Of Attitude", Information Systems Frontiers, 2019, vol. 21, pp. 565-580. DOI: https://doi.org/10.1007/s10796-019-09909-x
[15] M.M. Omarov, N.Y. Omarova and D.L. Minin, "Territory Branding Development As A Regional Economy Activation Factor", Lecture Notes in Networks and Systems (see books), 2020, vol. 87, pp. 270277. DOI: 10.1007/978-3-030-29586-8_32 EID: 2-s2.0-85072897409 